\title{
Urinary Peptidomic Analysis Identifies Potential Biomarkers for Acute Rejection of Renal Transplantation
}

\author{
Tara K. Sigdel • Xuefeng B. Ling • Ken H. Lau • Li Li • \\ James Schilling • Minnie M. Sarwal
}

Published online: 28 April 2009

(C) Humana Press 2009

\begin{abstract}
Introduction Human urine is a complex matrix of proteins, endogenous peptides, lipids, and metabolites. The level of any or all of these components can reflect the pathophysiological status of an individual especially of the kidney at the time of urine collection. The naturally occurring endogenous urinary peptides which are thought to be the product of several proteolytic and degradation processes may provide clinically useful biomarkers for different renal and systemic diseases.

Materials and Methods To examine if specific differences in the urinary peptidome $(<10 \mathrm{kDa})$ occur at the time of acute renal transplant rejection (AR), we undertook a study of urine samples collected from biopsy-proven AR $(n=10)$, stable graft function $(n=10)$, and healthy normal control $(n=10)$. The peptides $(<10 \mathrm{kDa})$ were extracted and fractionated with high-performance liquid chromatography followed by matrix-assisted laser desorption/ionization (MALDI) time-of-flight mass spectrometric (MS) analysis. Results We identified 54 endogenous peptides, including multiple peptides for Tamm-Horsfall protein (UMOD). A panel of peptides are identified which discriminate renal
\end{abstract}

T. K. Sigdel $\cdot$ L. Li $\cdot$ M. M. Sarwal

Division of Nephrology, Department of Pediatrics,

Stanford University Medical School, Stanford University,

Stanford, CA 94305, USA

X. B. Ling $\cdot$ K. H. Lau $\cdot$ J. Schilling

Divisions of Immunology, Department of Pediatrics,

Stanford University Medical School, Stanford University,

Stanford, CA 94305, USA

M. M. Sarwal ( $\square)$

Stanford University Medical School,

G306, 300 Pasteur Drive,

Stanford, CA 94304, USA

e-mail: msarwal@stanford.edu transplant patients with AR from stable graft. We have shown that liquid chromatography followed by MALDI is a useful tool to identify potential biomarkers, which after verification with larger patient cohort can be used as a noninvasive monitoring tool for renal transplant rejection.

Keywords Urine · Peptidomics · Biomarker .

Renal transplantation · Proteomics · LC MALDI ·

Urinary Peptidomics $\cdot$ Acute rejection .

Non-invasive biomarkers · Biomarker discovery

\author{
Abbreviations \\ AR Acute rejection \\ STA Stable graft function \\ HC Healthy normal control \\ THP Tamm-Horsfall protein \\ LC-MALDI Liquid chromatography followed by \\ matrix-assisted laser desorption/ionization \\ TNBS 2,4,6-Trinitrobenzenesulfonic acid
}

\section{Introduction}

Urine is rich in proteins and peptides that could sample both renal as well as systemic events [1]. Proteins and endogenous peptides resulting from processes that include glomerular filtration, apoptosis, and proteolytic degradations in urine may carry useful biomarkers for diseases including acute allograft rejection (AR) of renal transplant [2]. AR is a primary risk factor for graft functional decline, chronic rejection, and accelerated graft loss [3, 4]. Elevations in the serum creatinine are nonspecific and may result from many causes of graft dysfunction (e.g., acute tubular necrosis, infection, drug toxicity), and AR can occur 
without an associated rise in the serum creatinine. The invasive biopsy, the current gold standard, correlates poorly with treatment response and prognosis and has associated complications of pain, sedation, hematuria, arteriovenous fistulae, graft thrombosis, and transfusion risk [5]. Therefore, identification and validation of informative biomarkers for non-invasive monitoring for acute rejection is a critical unmet need in organ transplantation.

Urine has been analyzed to identify disease biomarkers for diseases including coronary artery disease [6], renal cell carcinoma [7], prostate cancer [8,9], diabetes [10], and renal diseases [11-16]. The analysis of naturally occurring small molecular weight (MW) endogenous peptide analysis is termed as "peptidomics." Techniques such as capillaryelectrophoresis-coupled mass spectrometric analysis (CE MS) [17, 18], liquid chromatography (LC) MS with off-line coupled combination of reversed-phase high-performance liquid chromatography (HPLC) and matrix-assisted laser desorption/ionization time of flight mass spectrometry (MALDI-TOF) [19], and magnetic bead separation followed by MALDI-TOF [20] have been used to study the urine peptidome. In this report, we develop and optimize a method to analyze endogenous urinary peptides ranging from 900 to 4,000 Da by label-free high-performance liquid chromatography coupled with MALDI-TOF analysis and identified potential biomarker peptides for acute rejection.

\section{Materials and Methods}

Samples

Thirty clinically annotated urine samples, collected as early-morning midstream voids (with urine protein dipsticks $\leq 1+$ ), were included in the study from three different clinical phenotypes: renal transplant patients with biopsyproven acute rejection (AR; $n=10$ ), normal protocol biopsies and stable graft function (STA; $n=10$ ), and ageand gender-matched healthy normal controls (HC; $n=10)$. The transplant patients were matched for gender, race, immunosuppression regimen, Donor type (living and deceased), and time post-transplant (Table 1). As graft function falls during an AR episode, as expected, the mean graft function, based on calculated creatinine clearance in milliliter per minute per $1.73 \mathrm{~m}^{2}$ [21], was lower for patients with AR $(85.1 \pm 46.7$ for AR and $121 \pm 30.0$ for STA; $P<0.01)$. Samples were collected between January 2005 and June 2007 as part of an ongoing Institutional Review Board-approved study at Stanford University from patients enrolled at Lucile Packard Children's Hospital at Stanford University.

Urine Collection, Initial Processing, and Storage

Fifty to $100 \mathrm{~mL}$ urine, collected in sterile containers, was centrifuged at $2,000 \times \mathrm{g}$ for $20 \mathrm{~min}$ at room temperature within $1 \mathrm{~h}$ of collection. The supernatant was separated from the pellet containing any particulate matter including cells and cell debris. The $\mathrm{pH}$ of the supernatant was adjusted to 7.0 and stored at $-80^{\circ} \mathrm{C}$ until further analysis.

\section{Recovery and Quantification of Urinary Protein}

The urine processing method has been previously described in detail by our group [22] and summarized in Fig. 1. Essentially, urinary proteins were isolated by centrifugal filtration through Amicon Ultra centrifugal filtration devices (10 kDa cutoff) (Millipore, Bedford, MA, USA), at 3,000 $\times \mathrm{g}$ for $10 \mathrm{~min}$ at $10^{\circ} \mathrm{C}$ using swinging bucket rotors. After equilibration, $10 \mathrm{~mL}$ of urine supernatant was centrifuged for $20 \mathrm{~min}$ at $3,000 \times g$ at $10^{\circ} \mathrm{C}$. The filtrate was recovered and saved for peptidomic analysis. The retentate was washed twice with $10 \mathrm{~mL} 20 \mathrm{mM}$ Tris- $\mathrm{HCl}$ (pH7.5). The final volume of the retentate was saved for a separate study of urinary proteins.

Extraction of Low-MW Endogenous Peptides

The filtrates containing the low-MW urinary endogenous peptides were extracted with Waters ${ }^{\circledR}$ Oasis ${ }^{\circledR}$ HLB Extraction Cartridges (Waters Corporation, Milford, MA, USA). Briefly,

Table 1 Patient demographics

\begin{tabular}{|c|c|c|c|c|c|c|}
\hline $\begin{array}{l}\text { Patient } \\
\text { group }\end{array}$ & $\begin{array}{l}\text { No. of } \\
\text { subjects }\end{array}$ & $\begin{array}{l}\text { Immunosuppression } \\
\text { (SF/SB) }\end{array}$ & $\begin{array}{l}\text { Gender } \\
(\mathrm{M} / \mathrm{F})\end{array}$ & $\begin{array}{l}\text { Donor } \\
\text { (living/cadaver) }\end{array}$ & Mean age & $\begin{array}{l}\text { Mean GFR } \\
\left(\mathrm{mL} / \mathrm{min} / 1.73 \mathrm{~m}^{2}\right)\end{array}$ \\
\hline AR & 10 & $5 / 5$ & $5 / 5$ & $5 / 5$ & $12 \pm 5$ & $83.3 \pm 52.2$ \\
\hline STA & 10 & $5 / 5$ & $5 / 5$ & $5 / 5$ & $12 \pm 5$ & $131.4 \pm 28.4$ \\
\hline $\mathrm{HC}$ & 10 & $\mathrm{n} / \mathrm{a}$ & $5 / 5$ & $\mathrm{n} / \mathrm{a}$ & $8 \pm 4$ & $\mathrm{n} / \mathrm{a}$ \\
\hline
\end{tabular}

Mean GFR by the Schwartz Formula [20], as expected, is significantly lower during the acute rejection episode when compared to patients without rejection $(p<0.01)$

$A R$ acute rejection, STA stable graft function, $H C$ healthy normal control, $S F$ steroid-free immunosuppression using tacrolimus and MMF maintenance, $S B$ steroid-based immunosuppression using steroids, tacrolimus, and MMF maintenance 
Urine

$10 \mathrm{AR}, 10 \mathrm{STA}$, and $10 \mathrm{HC}$

Centrifugal filtration

( $10 \mathrm{kDa}$ Cutoff)

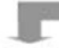

30 individual naturally occurring urinary peptides

(10AR, 10 STA and $10 \mathrm{HC})$

L

Peptide extraction

(Solid phase and ethyl acetate extraction)

Peptide assay

(TNBS Assay)

且

\section{Peptide quantification (TNBS assay)}

\&

Pooling of individual samples to three pools (AR, STA, and HC)

Peptide fractionation

$\left(C_{18}\right.$ reverse phase column)

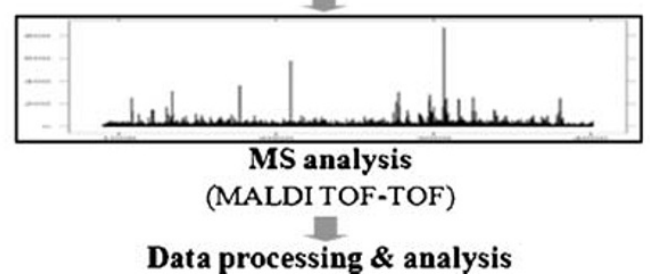

Fig. 1 A flowchart for peptidomic analysis of endogenous urinary peptides. The schematic for urinary peptide extraction and processing by LC MALDI method is shown. The detail of the method is presented in "Materials and Methods" section

the cartridges were activated with $2 \mathrm{~mL} 100 \%$ acetonitrile followed by equilibration with $5 \mathrm{~mL} 0.1 \%$ trifluoroacetic acid in water. The $\mathrm{pH}$ of the sample was adjusted to $\mathrm{pH} 3.0$ by addition of $50 \%$ trifluoroacetic acid (TFA) and passed through the cartridge with $10 \mathrm{~mL} / \mathrm{min}$ flow rate. The cartridge was washed with $5 \mathrm{~mL} 0.1 \%$ TFA in water and eluted with $3 \mathrm{~mL} 70 \%$ acetonitrile/0.1\%TFA (flow rate no faster than $10 \mathrm{~mL} / \mathrm{min}$ ). The volume of the eluted peptides was brought to $0.5 \mathrm{~mL}$ by the use of SpeedVac. The peptides were extracted with $1 \mathrm{~mL}$ ethyl acetate by vortexing for $1 \mathrm{~min}$. The aqueous layer was recovered by discarding the upper organic layer, and the volume of the extract was brought to $500 \mu \mathrm{L}$ by SpeedVac centrifugation.

Quantification of Endogenous Peptides and Proteins

2,4,6-Trinitrobenzenesulfonic Acid Assay The small-MW peptides were quantified using a method published elsewhere [23]. Briefly, a standard curve was generated with glycine solution $(10,20,30,40,50,60,70,80 \mu \mathrm{M})$. Absorbance at $420 \mathrm{~nm}$ by 2,4,6-trinitrobenzenesulfonic acid (TNBS) was measured.

Creatinine Assay Urine creatinine was measured using Quantichrom $^{\mathrm{TM}}$ Creatinine Assay Kit (DICT-500) (BioAssay
Systems, Hayward, CA, USA). The manufacturer's manual was followed for the assay.

Protein assay and Normalization The large-MW protein fraction was quantified by bicinchoninic acid protein assay (Pierce, Rockford, IL, USA). We used 2,4,6-trinitrobenzenesulfonic acid assay to normalize the peptide load onto the LC fractionation. Since the samples have varied peptide concentration as measured by the TNBS assay, we created pools of samples to normalize for equal peptide content contribution from each individual sample. Aliquots containing $10 \mathrm{nmol}$ were added from each individual samples in all the three phenotypes (AR, STA, and HC) to make a pool of $100 \mathrm{nmol}$ peptides for each phenotype.

\section{Sample Fractionation}

Three nanomoles peptides were injected on a $100 \mu \mathrm{m} \times$ $15 \mathrm{~cm} \mathrm{C} \mathrm{C}_{18}$ reverse-phase column (Michrom) and eluted with a gradient of $5 \%$ to $55 \%$ acetonitrile over $50 \mathrm{~min}$ using a Michrom MS4 HPLC. Twenty-second fractions were collected onto MALDI targets with a Probot fraction collector (LC Packings). A total of 100 fractions were collected and analyzed on 4700 MALDI-TOF/TOF (Applied Biosystems) in MS mode. One microliter of matrix solution containing $4.8 \mathrm{mg} / \mathrm{ml} \alpha$-cyano-4-hydroxycinnamic acid (Agilent Technologies, Palo Alto, CA, USA and $30 \mathrm{fmol} / \mu \mathrm{l}$ glu-fibrinopeptide (Sigma-Aldrich, St. Louis, MO, USA) was automatically deposited by the Probot on each spot.

\section{MS Data Collection and Analysis}

To ensure reproducibility and robustness of measured signal, three MS scans of 2,000 laser shots per spot were performed for each MALDI plate. Ionization of glufibrinopeptide was used as an internal control peptide and was used for normalization of signal across experiments. The MS data were collected in terms of mass to charge $(\mathrm{m} / \mathrm{z})$ ratio, signal intensity, and the retention time. A key step of data processing, transforming the large volume of raw data into a list of nonredundant cross-category $\mathrm{m} / \mathrm{z}$ features, while simultaneously tracking associated sample source, retention time, and intensity, was performed with the help of an inhouse informatics platform, "MASS-Conductor" (Ling, unpublished). MASS-Conductor is an integrated suite of algorithms, statistical methods, and computer applications that interfaces with ABI, Thermo, and Agilent instrument databases and discovers discrimative peptide features and performs sample classification from protein mass spectrometry data. MASS-Conductor implementation does two dimensional clustering and tracks both $\mathrm{m} / \mathrm{z}$ and HPLC retention time to define mono-isotopic peak features. The peak-finding and subsequent peak/retention time clustering procedure were 
developed and improved from previous descriptions [24, 25]. Figure 2 illustrates the biomarker discovery flow chart using MASS-Conductor data mining tools to process HPLC data sets.

Peptide Identification

Selected candidate biomarker peptides were analyzed by tandem mass spectrometry (MS/MS) using a 4700 MALDITOF/TOF (Applied Biosystems) in MS/MS mode. All MS/MS data were submitted for MASCOT database search for identification purpose. All positive peptides identified were manually reviewed.

\section{Statistical Analysis}

After retrieving the signal intensities for the endogenous peptides from AR, STA, and $\mathrm{HC}$, the relative ratio values normalized against healthy control for AR/STA vs. HC were calculated by the signal of AR/STA divided by the signal of HC. The fold changes (AR vs. HC or STA vs. HC) were then calculated based on these relative ratios. To determine the high (or low) expression abundance and up(or down-) regulation in AR phenotype, two criteria were used: (a) Fold change of AR vs. HC was larger (or less) than 0 and (b) Fold change of AR vs. HC was larger (or less) than the fold change of STA vs. HC. Therefore, four groups of peptide signal intensity were categorized as (1) high abundance and up-regulation in AR, (2) low abundance and up-regulation in AR, (3) high abundance and down-regulation in AR, and (4) low abundance and down- regulation in AR. The box plots were drawn based on the fold changes in each group; in addition, the line graphs show that the signal intensity for each individual peptide either increased or decreased in AR vs. STA.

LC MALDI on Individual Samples to Verify Most Significant Peptide Biomarkers

We analyzed the 30 individual urine samples included in the first discovery phase along with ten individual urine samples from nonspecific proteinuric patients. The peptide samples for analysis were prepared and processed by the method, schematic of which is presented in Fig. 1.

\section{Results}

Protein and Peptide Recovery

We previously established a standard protocol for urine collection and processing for urinary proteomics analysis [22]. We followed the protocol to collect two separate fractions of small-MW endogenous peptides and large-MW proteins. Since our aim was to identify AR-specific endogenous peptides, the filtration method using a membrane with $10 \mathrm{kDa}$ cutoff size served ideally.

When assayed by sodium dodecyl sulfate polyacrylamide gel electrophoresis and linear mode MALDI-TOF, the filtrates were found to be smaller than $6 \mathrm{kDa}$ molecular size (data not shown). The small-MW peptide fraction present in the filtrate was quantified by 2,4,6-trinitrobenzenesulfonic
Fig. 2 Data processing pipeline for peptidomic analysis using LC MALDI. Data processing involved transformation of large volume of raw into a list of nonredundant cross-category $\mathrm{m} / \mathrm{z}$ features keeping track of sample source, retention time, and intensity. MASS-Conductor is an integrated suite of algorithms, statistical methods, and computer applications that interface with Applied Biosystems (Foster City, CA, USA), ThermoElectron (Waltham, MA, USA), and Agillent Biotechnologies (Palo Alto, CA, USA) instrument databases and discover discrimative peptide features and perform sample classification from protein mass spectrometry data

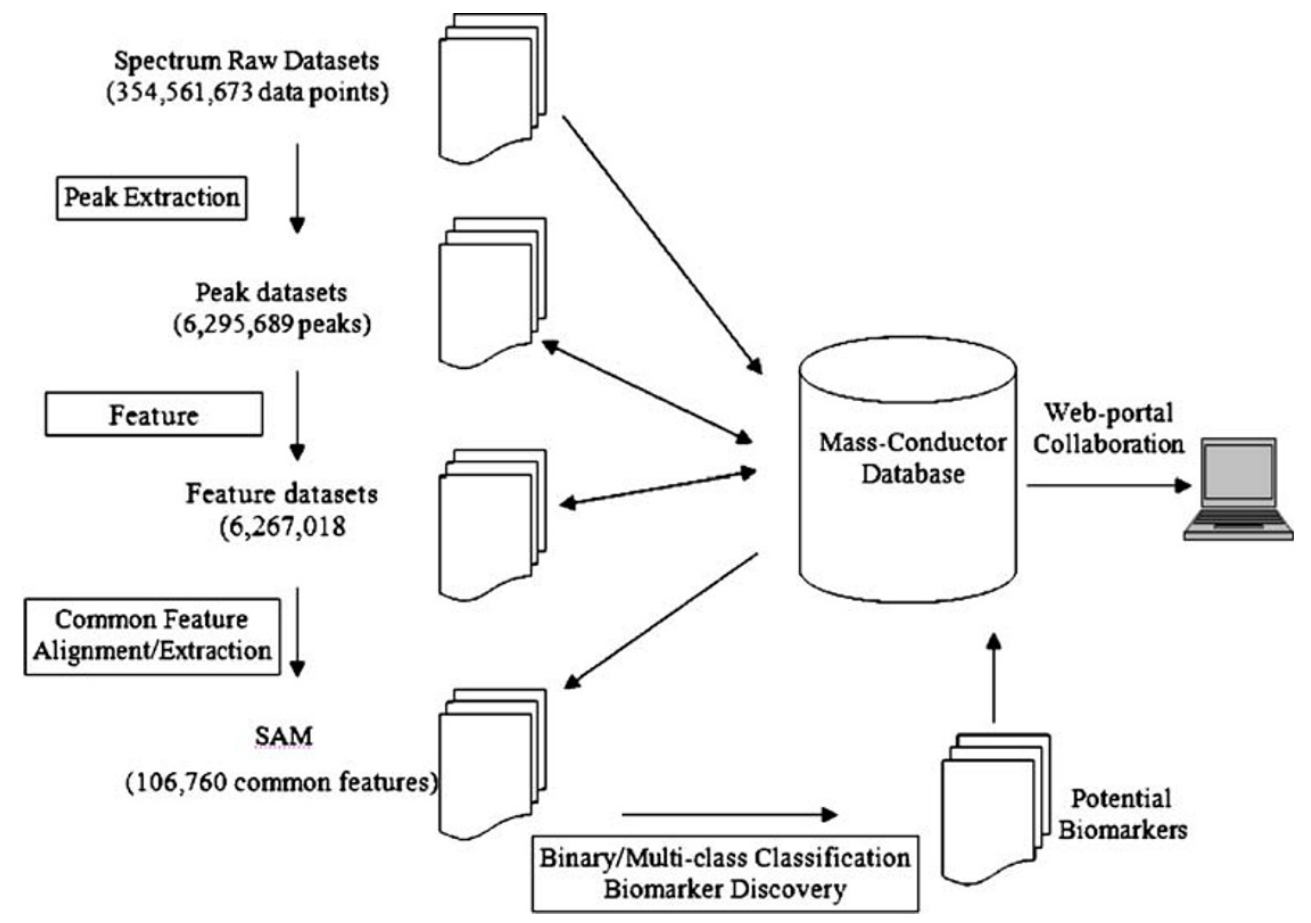


acid assay which is based on the measurement of primary amines and measuring the TNBS-primary amine conjugate [26]. The mean peptide concentration in AR, STA, and HC categories was $156.5 \pm 108.8,344.6 \pm 121.5$, and $378.4 \pm$ $130.1 \mu \mathrm{mol} / \mathrm{dL}$, respectively. The mean protein concentration was $6.8 \pm 3.8,7.82 \pm 2.2$, and $5.5 \pm 1.7 \mathrm{mg} / \mathrm{dL}$ in samples from $\mathrm{AR}, \mathrm{STA}$, and $\mathrm{HC}$, respectively. The mean urine creatinine concentration was $59.1 \pm 49.3,104.4 \pm 41.7$, and $102.9 \pm$ $38.2 \mathrm{mg} / \mathrm{dL}$ for AR, STA, and HC, respectively. Since proteinuric urine samples were not included in the study, there was no statistically significant difference in urine protein concentration among the three categories of samples.

\section{LC MALDI Analysis of Small-MW Endogenous Peptides}

We tested for the optimal amount of endogenous peptides to be fractionated for LC MALDI analysis. Results based on the mass spectrometric data suggested 3 nmol equivalents as the optimum amount (data not presented). Comparison of analysis by spotting direct to plate vs. LC MALDI showed large increase in number of features with the HPLC fractionation followed by MALDI MS analysis. The MS data consisted of a set of three sets of data points: the retention time dimension, the $\mathrm{m} / \mathrm{z}$ dimension, and the intensity dimension. The "MASS-Conductor" software was used to transform the large volume of raw data into a list of nonredundant cross-category $\mathrm{m} / \mathrm{z}$ features while simultaneously tracking associated sample source, retention time, and intensity. Figure 2 illustrates the biomarker discovery flow chart using Mass-Conductor data mining tools to process LC MS data sets from pooled samples of respective AR, STA, and HC categories. The analysis of ten repeated LC MALDI scan of the three pooled samples of classes AR, STA, and HC yielded 42.99 GB of raw data points (354,561,673 rows of records), 2.99 GB peak data points (6,295,689 rows of records), $528 \mathrm{MB}$ monoisotopic feature (ion containing only the most abundant isotopes) data points (6,267,018 rows of records), and 10.52 MB unique monoisotopic feature data points across categories (106,760 rows of records) equivalent to 26,690 peptides.

We analyzed MS data for AR-specific endogenous peptides in terms of their relative abundance when compared to their abundance in STA and HC. A set of 73 potential peptide biomarker candidates have been identified whose level is 1.5 -fold more or less in AR compared to STA (Table 2). We calculated ratio of peptide signal intensity and classified them as high abundance and low abundance peptides by comparing their abundance with their level in HC. We classified them into a total of four groups. The first group comprised of (1) increased peptide presence in AR and high abundance ( $n=6$; Fig. 3D (II)), (2) increased peptide presence in AR and low abundance $(n=$ 31; Fig. 3B), (3) decreased peptide presence in AR and high abundance, ( $n=5$; Fig. $3 \mathrm{~A}$, and (4) decreased peptide presence and low presence $(n=31$; Fig. $3 \mathrm{C})$. The box plots were drawn based on the fold changes in each group (Fig. 3).

Identification of Potential Biomarker Endogenous Peptides

The 73 peptides listed in Table 2 were subjected to identification by tandem mass spectrometry. To date, we have identified 44 including several peptides originating from proteins including collagen alpha-1(I) chain (COL1A1), collagen alpha-3(V) chain (COL5A3), thyroid receptorinteracting protein 6 (TRIP6), uromodulin (UMOD), albumin D box-binding protein (DBP), B-2 microglobulin (B2M), kininogen-1 (KNG1), protocadherin-1 (PCDH1), alpha-1microglobulin (AMBP), prostaglandin-H2 D-isomerase (PTGDS), cartilage intermediate layer protein (CILP), Zn finger protein 14 (ZNF14), vascular non-inflammatory molecule 2 (VNN2), etc. These identifications include single peptide per protein to multiple peptides per protein. A sample MS/MS spectrum for a peptide from Tamm-Horsfall protein (THP) is shown in Fig. 4 with corresponding MS in the inset. There was no overwhelming presence of peptides from highabundance plasma proteins unlike in proteomics of intact proteins using 2D DIGE in our studies using the urine of renal transplant patients [22].

Verification of Most Significant Candidate Peptides by LC MALDI on Individual Patients

We tested for the trueness of discovery of peptides with MW of 1654.91, 1680.97, 1755.95, 1768.01, 1912.06, and $2040.16 \mathrm{Da}$ on individual samples included in initial discovery set (ten AR, ten STA, and ten HC, ten patients with non-specific kidney injury (NS). Average normalized signal intensities of the ten samples in each class have been plotted with standard error of the mean (SEM; Fig. 5). Student's $t$ test $P$ values are calculated for each peptide when the signal intensity was compared with other phenotypes. All the peptides tested could be verified by analyzing their presence in individuals in 40 individual samples across the four phenotypes.

\section{Discussion}

Urinary peptides may provide much needed non-invasive biomarkers for early diagnosis of acute rejection of renal transplant. Unlike proteomics, where a smaller number (hundreds), of larger-MW proteins are assessed, peptidomics examines thousands of small-MW endogenous peptides in [27]. Several top-down approaches have been used to analyze naturally occurring endogenous peptides. Currently, 
Table 2 List of peptides and their relative abundance in terms of fold change in AR urine when compared to STA urine with the ID of peptides that are sequenced

$\begin{array}{llllll}m / z \text { (Da) } & \begin{array}{l}\text { Fold } \\ \text { change }\end{array} & \begin{array}{l}\text { Swiss } \\ \text { Prot ID }\end{array} & \text { Gene } & \text { Parent protein } & \text { Peptide sequence }\end{array}$

High-abundance peptides

$\begin{array}{crr}\begin{array}{c}\text { Increase in AR } \\ (n=6)\end{array} & 1,168.64 & 22.7 \\ & 2,096.98 & 5.0 \\ & 1,828.85 & 3.0 \\ & 2,176.00 & 1.8 \\ & 968.58 & 1.7 \\ & 1,468.81 & 1.5 \\ \text { Decrease in AR } & 1,082.70 & 20.3 \\ (n=5) & 994.11 & 12.4 \\ & 1,438.80 & 3.1 \\ & 1,518.80 & 2.9 \\ & 1,843.90 & 2.4\end{array}$

Low-abundance peptides

\begin{tabular}{|c|c|c|c|c|c|}
\hline \multirow{29}{*}{$\begin{array}{l}\text { Increase in AR } \\
\text { urine }(n=31)\end{array}$} & $1,218.55$ & 6.6 & & & \\
\hline & $1,717.79$ & 5.6 & P17017 & ZNF14 & Zn Finger Protein \\
\hline & $2,008.94$ & 5.3 & P25940 & COL5A3 & Collagen alpha-3(V) chair \\
\hline & $2,206.00$ & 5.0 & P02452 & COL1A1 & Collagen Alpha-1(I) chain \\
\hline & $1,202.55$ & 4.8 & Q08174 & PCDH1 & Protocadherin-1 \\
\hline & $1,235.52$ & 4.4 & P25940 & COL5A3 & Collagen alpha-3(V) chair \\
\hline & $1,060.58$ & 4.2 & & & \\
\hline & $1,322.61$ & 3.6 & P25940 & COL5A3 & Collagen alpha-3(V) chair \\
\hline & $1,963.86$ & 3.5 & O95498 & $V N N 2$ & $\begin{array}{l}\text { Vascular non-inflammator } \\
\text { molecule } 2\end{array}$ \\
\hline & $1,992.97$ & 3.1 & P25940 & COL5A3 & Collagen alpha-3(V) chair \\
\hline & $1,028.54$ & 2.8 & Q10586 & $D B P$ & $\begin{array}{l}\text { Albumin D box-binding } \\
\text { protein }\end{array}$ \\
\hline & $2,129.99$ & 2.7 & P20908 & COL5A1 & $\begin{array}{l}\text { Collagen alpha-1 (V) } \\
\text { chain }\end{array}$ \\
\hline & $1,614.83$ & 2.6 & & & \\
\hline & $1,076.56$ & 2.3 & O60909 & $B 4 G A L T 1$ & $\begin{array}{l}\text { Beta-1,4- } \\
\text { galactosyltransferase } 2\end{array}$ \\
\hline & $1,160.55$ & 2.2 & P25940 & COL5A3 & Collagen alpha-3(V) chair \\
\hline & $1,130.63$ & 2.1 & P07911 & $U M O D$ & Uromodulin \\
\hline & $1,101.52$ & 2.0 & P39060 & COL18A1 & $\begin{array}{l}\text { Collagen alpha-1 } \\
\text { (XVIII) chain }\end{array}$ \\
\hline & $1,061.40$ & 1.9 & & & \\
\hline & $2,466.12$ & 1.8 & & & \\
\hline & $2,881.26$ & 1.8 & & & \\
\hline & $1,047.48$ & 1.8 & P07911 & $U M O D$ & Uromodulin \\
\hline & $1,039.44$ & 1.8 & & & \\
\hline & $2,327.02$ & 1.7 & & & \\
\hline & $1,142.51$ & 1.7 & P39060 & COL18A1 & $\begin{array}{l}\text { Collagen alpha-1 } \\
\text { (XVIII) chain }\end{array}$ \\
\hline & 982.36 & 1.7 & & & \\
\hline & $1,117.47$ & 1.6 & & & \\
\hline & $1,069.60$ & 1.6 & P07911 & $U M O D$ & Uromodulin \\
\hline & $2,636.20$ & 1.5 & & & \\
\hline & $2,572.21$ & 1.5 & & & \\
\hline
\end{tabular}

DGPPGPPGERGPQGPQGPV

Collagen alpha-1

(XI-chain)

P25940 COL5A3 Collagen alpha-3(V) chain

P07911 UMOD Uromodulin

P07911 UMOD Uromodulin

P61769 B2M

B-2 microglobulin

B-2 microglobulin

Prostaglandin-H2

D-isomerase

QPGATGQPGPKGDVGQDGAPGIPG

SRVLNLGPI

VIDQSRVLNLGPIT

IQRTPKIQV

LSQPKIVKWDRDM

YSQGSKGPGEDFRMATL

YQEYEKQPCKCKAV

ERGPPGSRGERGQPGATGQP

ADGQPGAKGEPGDAGAKGDAGPPGP

EEQPPNTLIGS

QGVVGPSGPPGPPG

GEPGPDGPPGRTGP

PQVNWIPCQDPHRFGH

IGPPGEAGEKGDQGLPGVQGP

PGGAPLPPPPP

DGPEGPKGRGGPNGDPGPLGPPG

MSRLLGGTLE

PGQPGIRGPAGH

SVIDQSRVLN

PPGPPGPPGPPS

SGSVIDQSRV

GPPGPPGPPGPPS

SRVLNLGPIT 
Table 2 (continued)

\begin{tabular}{|c|c|c|c|c|c|c|}
\hline & $m / z$ (Da) & $\begin{array}{l}\text { Fold } \\
\text { change }\end{array}$ & $\begin{array}{l}\text { Swiss } \\
\text { Prot ID }\end{array}$ & Gene & Parent protein & Peptide sequence \\
\hline \multirow{33}{*}{$\begin{array}{l}\text { Decrease in AR } \\
\text { urine }(n=31)\end{array}$} & $2,236.10$ & 1.5 & P27658 & COL8A1 & $\begin{array}{l}\text { Collagen alpha-1 } \\
\text { (VIII) chain }\end{array}$ & QDGIPGQPGFPGGKGEQGLPGLP \\
\hline & $1,558.70$ & 1.5 & P41222 & PTGDS & $\begin{array}{l}\text { Prostaglandin- } \mathrm{H} 2 \\
\text { D-isomerase }\end{array}$ & YSQGSKGPGEDFRM \\
\hline & $1,680.97$ & 78.9 & P07911 & $U M O D$ & Uromodulin & VIDQSRVLNLGPITR $^{\mathrm{a}}$ \\
\hline & $2,604.30$ & 35.2 & P61769 & $B 2 M$ & B-2 microglobulin & LKNGERIEKVEHSDLSFSKDWS \\
\hline & $1,615.90$ & 14.8 & & & & \\
\hline & $1,912.06$ & 12.8 & P07911 & $U M O D$ & Uromodulin & SGSVIDQSRVLNLGPITR $^{\mathrm{a}}$ \\
\hline & 956.53 & 8.9 & Q15654 & TRIP6 & $\begin{array}{l}\text { Thyroid receptor- } \\
\text { interacting protein } 6\end{array}$ & QGRAIPRGT \\
\hline & $1,303.70$ & 8.5 & P02760 & $A M B P$ & $\begin{array}{l}\text { AMBP Alpha-1- } \\
\text { microglobulin }\end{array}$ & YGRAPQLRETL \\
\hline & $1,894.60$ & 7.6 & & & & \\
\hline & $1,663.60$ & 6.1 & & & & \\
\hline & $1,524.90$ & 6.0 & P07911 & $U M O D$ & Uromodulin & DQSRVLNLGPITR \\
\hline & $1,854.00$ & 5.6 & P25940 & COL5A3 & $\begin{array}{l}\text { Collagen alpha-3 } \\
\text { (V) chain }\end{array}$ & CLLLAALQLLPGTQADPV \\
\hline & $2,436.20$ & 5.0 & & & & \\
\hline & $1,502.80$ & 5.0 & & & & \\
\hline & $2,436.20$ & 5.0 & & & & \\
\hline & $1,502.80$ & 5.0 & & & & \\
\hline & $1,631.90$ & 4.5 & P61769 & $B 2 M$ & B-2 microglobulin & LLKNGERIEKVEHSDL \\
\hline & 982.61 & 3.6 & P07911 & $U M O D$ & Uromodulin & VLNLGPITR \\
\hline & $1,755.95$ & 3.4 & P07911 & $U M O D$ & Uromodulin & SGSVIDQSRVLNLGPIT $^{\mathrm{a}}$ \\
\hline & $1,768.01$ & 3.3 & P07911 & $U M O D$ & Uromodulin & SVIDQSRVLNLGPITR $^{\mathrm{a}}$ \\
\hline & $1,654.91$ & 2.8 & P07911 & $U M O D$ & Uromodulin & SGSVIDQSRVLNLGPI \\
\hline & $1,541.80$ & 2.5 & & & & \\
\hline & $1,188.70$ & 2.4 & P01042 & $K N G 1$ & Kininogen-1 & KRPPGFSPFR \\
\hline & $1,204.60$ & 2.2 & Q08174 & PCDH1 & Protocadherin-1 & EEQPPNTLIGS \\
\hline & $2,040.16$ & 2.2 & P07911 & $U M O D$ & Uromodulin & RSGSVIDQSRVLNLGPITR $^{\mathrm{a}}$ \\
\hline & $1,204.70$ & 2.2 & P25940 & COL5A3 & $\begin{array}{l}\text { Collagen alpha-3 } \\
\text { (V) chain }\end{array}$ & QPPVLGHGPRF \\
\hline & $2,386.10$ & 2.2 & & & & \\
\hline & $1,578.70$ & 2.0 & O75339 & CILP & $\begin{array}{l}\text { Cartilage intermediate } \\
\text { lauer protein }\end{array}$ & VGRCPVKTCAGQQDN \\
\hline & $1,423.80$ & 2.0 & P07911 & $U M O D$ & Uromodulin & SVIDQSRVLNLGPI \\
\hline & $1,736.90$ & 2.0 & & & & \\
\hline & $2,955.30$ & 1.9 & & & & \\
\hline & $2,311.00$ & 1.6 & & & & \\
\hline & $1,537.20$ & 1.5 & & & & \\
\hline
\end{tabular}

\footnotetext{
${ }^{\text {a }}$ Peptides verified in individual samples as illustrated in Fig. 5.
}

two preferred methods in peptidomics are CE MS [28] and LC MS [29-31]. Using CE MS method, Wittke et al. analyzed urine samples collected from renal transplant patients with AR, STA, and urinary tract infection and identified a distinct polypeptide pattern [17]. LC-based, LC MS approach usually involves three main steps: (1) extraction of peptides, (2) fractionation of extracted peptides using HPLC, and (3) MS analysis of fractionated peptides for biomarker discovery purpose. Different strategies could be applied to fractionate the mixture of peptides. We used LC MALDI to identify potential biomarkers that could potentially be used as diagnostic surrogate biomarkers for acute kidney transplant rejection.

We have made several important findings in this study. Firstly, we have demonstrated that pooled strategy is a viable way to screen for potential biomarker peptides in urine. High throughput "omic" methods require a considerable amount of time per sample to be analyzed. There are 
Fig. 3 Box plots for four categories of endogenous urinary peptides signal intensities when normalized against their presence in normal healthy control. Top panel low-abundance peptides. A Increase in acute rejection $(A R)$ than stable graft function (STA). B Decrease in AR than STA. Bottom panel high abundance peptides.

C Increase in AR than STA.

D Decrease in AR than STA.

The boxes are bounded by 75 th and 25 th percentiles of the data, and the whiskers extend to the minimum and maximum values
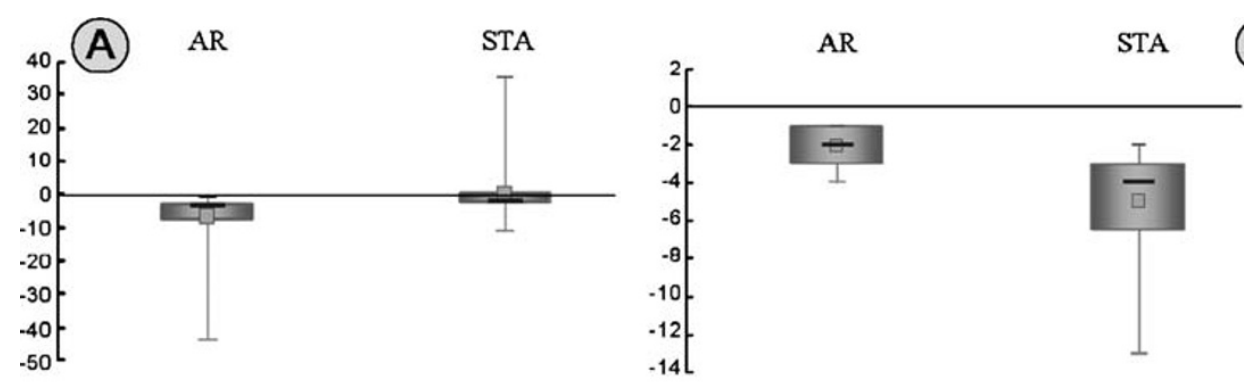

(B)
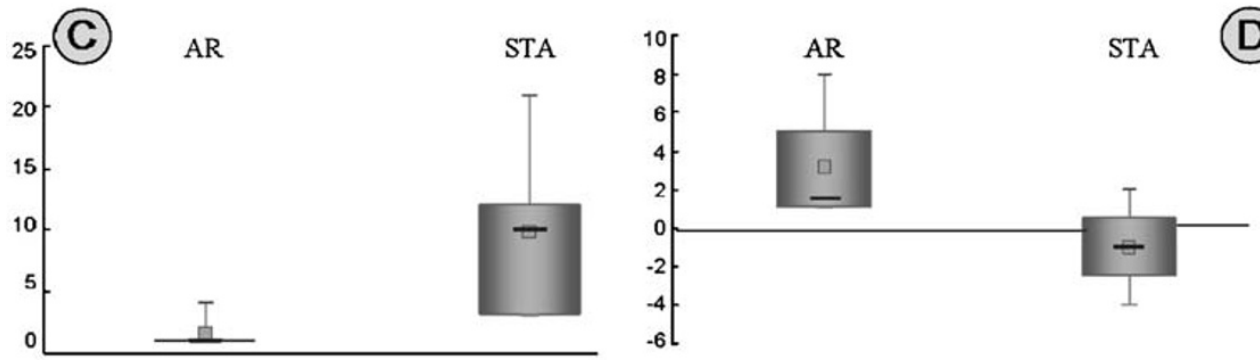

Mean - Median

conflicting opinions about pooled strategy. It is not advisable to pool samples wherever the aim is to identify very low abundance peptides because of the risk of losing the signal [32]. However, pooling strategy helps in quickly screening for most significant candidates and proceeds further in the biomarker pathway with verification with individual samples.

In this effort to discover endogenous peptides that discriminate AR from stable graft, we had to address several confounding issues. Patient urine may have a variable peptide concentration, dependent on the individual's meal, drink, and sleep patterns [33], which requires data to be normalized [34]. In the absence of a consensus "housekeeping" peptide for normalization, we choose a strategy that was best available to us. To normalize total peptide used per analysis, we loaded equal amount $(3 \mathrm{nmol})$ as quantified by TNBS assay. Another important factor is the ionization efficiency of the mass spectrometer employed for MS analysis. We used glu-fibrinopeptide as internal control for ionization efficiency and performed three MS scans of 2,000 laser shots per scan moving the laser every 50 shots.

Fig. 4 A sample spectrum of acute rejection (AR) specific peptide from MALDI-MS/MS A MS/MS spectrum used for sequencing of one of the of $A R$ specific peptides from UMOD $(\mathrm{m} / \mathrm{z}=1,912.06 \mathrm{Da})$ was made by MS/MS analysis is shown. In the inset: portion of MALDI MS spectrum of showing peptide peak for the same peptide $(\mathrm{m} / \mathrm{z}=1,912.06 \mathrm{Da})$

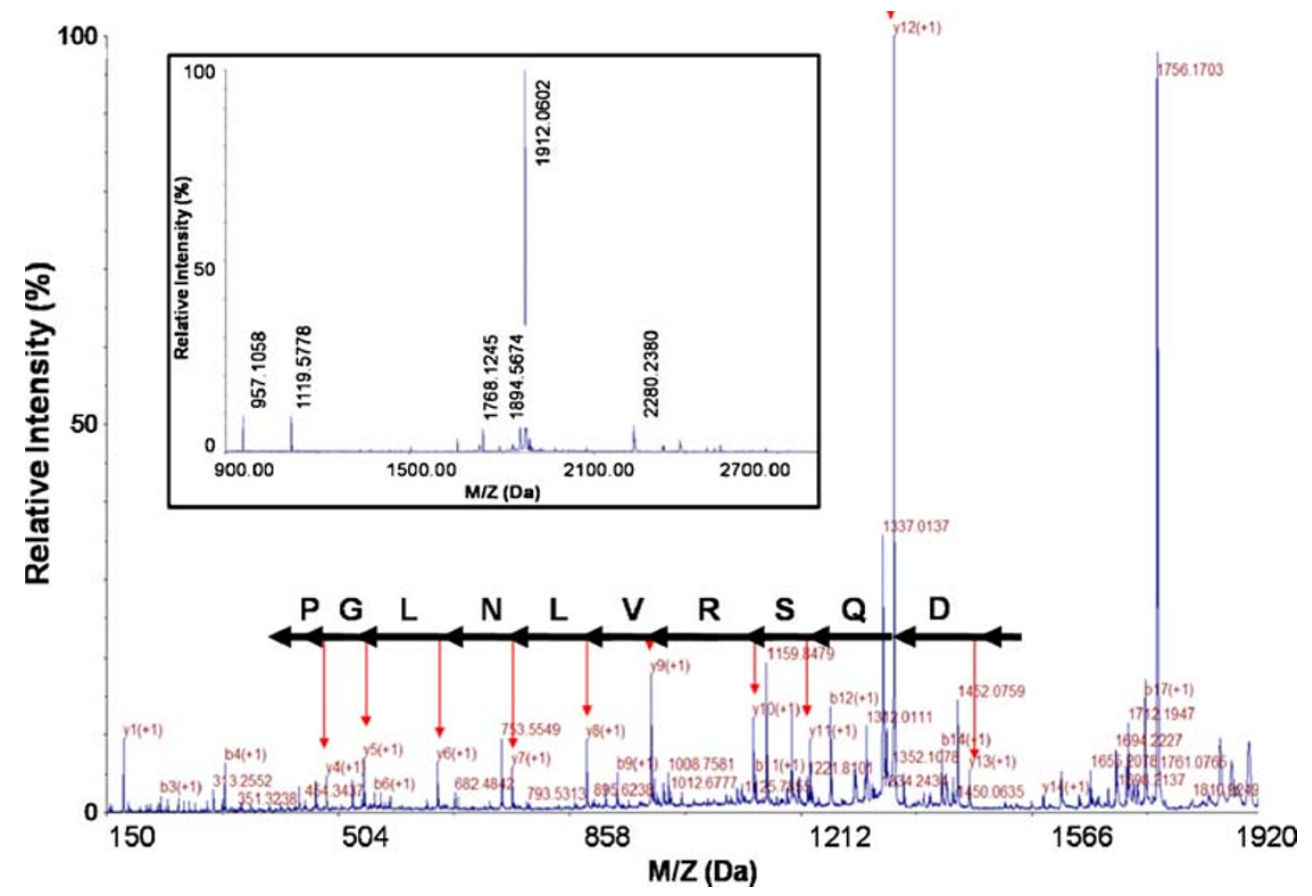


Fig. 5 An evaluation of the trueness of the discovery made by pooled samples with LC MALDI. A measurement of potential peptide biomarkers was made using individual urine from ( 1 ten acute rejection; 2 ten stable graft function; 3 ten healthy control; and 4 ten nonspecific proteinuria (NS). Average normalized signal intensities of the ten samples in each category have been plotted with SEM
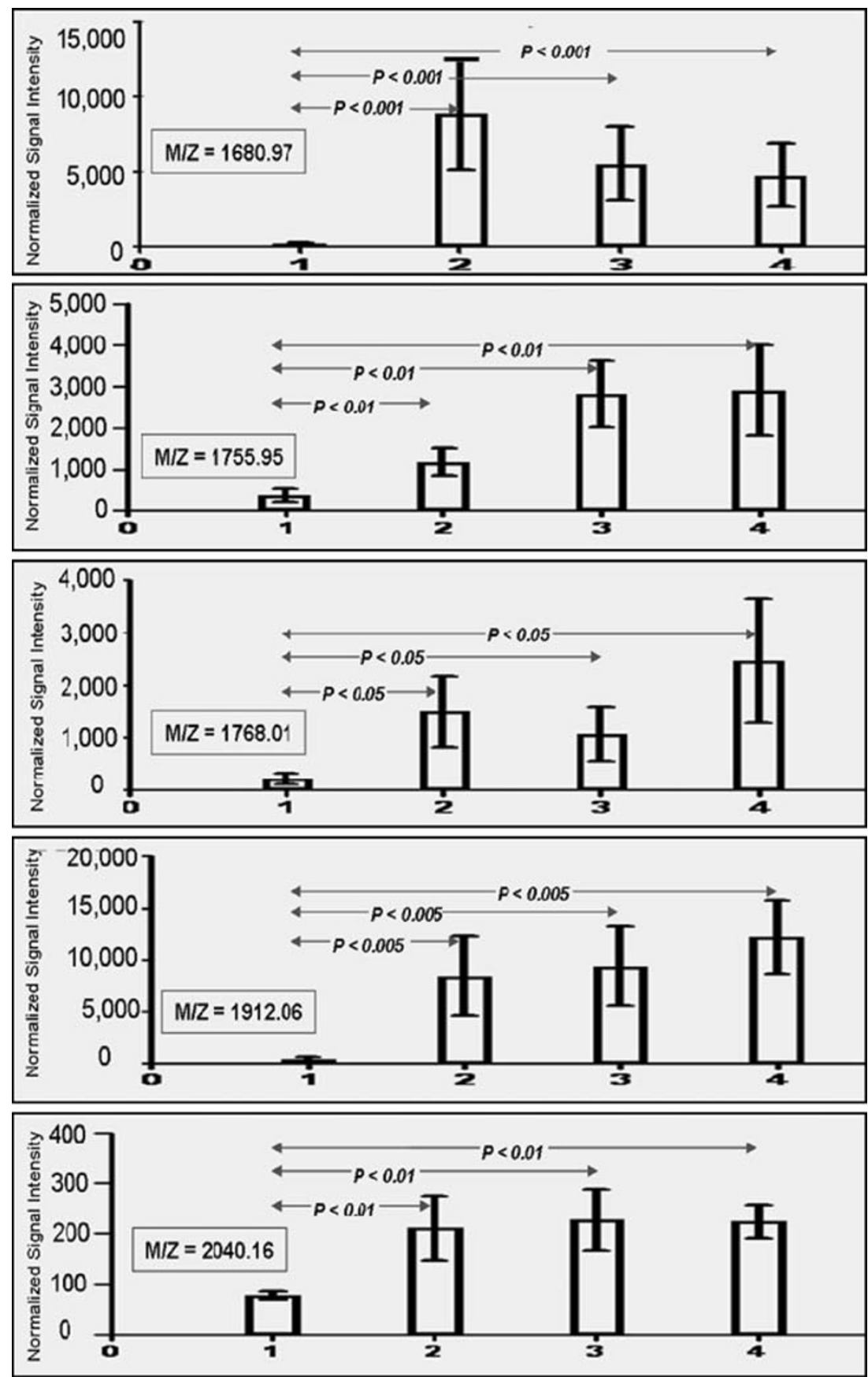

The third important outcome of the study is that we hypothesized that AR-specific signature exists among endogenous urinary peptides. The results from our study showed that such peptides in fact exist (Table 2). The peptides could be classified in four distinct classes as shown in Fig. 3. Those four panels provided peptide candidate biomarkers that collectively distinguish urine from acute rejection patients from patients with stable graft function. We verified the trueness of the discovered peptide biomarkers resulted from the pooled approach using MALDI-TOF, by analyzing five most significant peptides on individual urine from ten $A R$ patients and ten patients with stable graft function, including ten urine samples from nephrotic syndrome urine and ten urine collected from healthy normal controls. The successful verification of these peptides supported our pooled approach in initial screening of biomarkers.

Yet another achievement of this study is that we have identified 54 peptide fragments among 73 listed in Table 2. Even though identification endogenous peptides is more difficult compared to proteolytically cleaved peptides such as trypsin digested peptides, we identified several endogenous peptides which belong to either proteins of either renal origin 
or related with kidney dysfunction. Among the proteins identified include Tamm-Horsfall protein (UMOD), the most abundant protein in human urine; $\beta-2$ microglobulin (B2M), a cleaved product as well as the intact protein which has been reported as potential biomarker protein for AR by two independent groups [13, 35]; kininogen (KNG1), reported to be related to pathophysiology of hypertension and renal diseases [36]; and prostaglandin-H2 D-isomerase is reported to be expressed in kidney tubules (Human Protein Atlas-http://proteinatlas.org).

Finally, a number of peptide fragments of Tamm-Horsfall protein were observed to be significantly lower in AR urine when compared to STA urine and the urine collected from healthy normal controls. Trueness of this finding has been verified by analyzing individual samples. This observation of peptide fragments from other kidney-specific proteins may be an indication of a possible role of protease and protease inhibitor activities at the time of acute rejection. In an ongoing gene-expression analysis of biopsies of AR and STA patients, we have observed significantly low expression of UMOD gene $(P=0.008)$ in a total of 64 biopsy microarrays that included $19 \mathrm{AR}$ and 45 non-AR biopsy samples (Sarwal et al. 2008, unpublished data). This observation of a consistent low expression of UMOD at the transcript level as well its peptides may help us achieve a better insight on possible events associated with AR and even to investigate THP, physiological role of which has intrigued many researchers.

The observation of altered concentration of THP peptides in acute rejection vs stable graft will have to be investigated further with specific focus on the role of proteases and protease inhibitor activities. One of the ways to study such activity is to look for their cleavage pattern to see if they indicate activation of any specific protease/s. In a published report, Villanueva et al. identified a signature subset of serum peptides for three types of solid tumors but also to link peptide marker profiles for disease conditions directly to differential protease activity [37]. Such study in case of urinary peptides is possible with a larger patient cohort and with appropriate in vitro assays which is out of scope for this focused report on screening for potential biomarkers.

The important clinical utility aspect of this study is that the identified potential biomarker peptides will be verified in subsequent verification step using quantitative approach such as Multiple Reaction Monitoring (MRM) or enzyme-linked immunosorbent assays. Such quantitative analysis on a larger cohort of independent samples will help shorten the list of biomarkers which then could be taken to clinical trial.

\section{Conclusion}

In summary, for the first time, we have shown that LC MALDI is a useful tool to screen for potential non-invasive urinary peptide biomarkers for acute rejection. We identified a set of peptides as potential biomarkers for AR. We tested the trueness of the discovery on five of the most significant peptide candidates and demonstrated that LC MALDI on pooled urine samples for discovery is a reliable strategy for screening phase of biomarker discovery. A verification study is now necessary to further the outcome of this study, which is underway with more patients and disease categories included.

Acknowledgment The work was supported by NIH Grant RO1-AI061739, awarded to MS, and Deans Fellowship and Child Health Research Program Fellowship to TS. We thank Tonya Pekar and members of the Sarwal Lab for their help in the preparation of the manuscript.

\section{References}

1. Pisitkun T, Johnstone R, Knepper MA. Discovery of urinary biomarkers. Mol Cell Proteomics. 2006;5:1760-71.

2. Veenstra TD, Conrads TP, Hood BL, Avellino AM, Ellenbogen RG, Morrison RS. Biomarkers: mining the biofluid proteome. Mol Cell Proteomics. 2005;4:409-18.

3. Gulanikar AC, MacDonald AS, Sungurtekin U, Belitsky P. The incidence and impact of early rejection episodes on graft outcome in recipients of first cadaver kidney transplants. Transplantation. 1992;53:323-8.

4. Hariharan S, Johnson CP, Bresnahan BA, Taranto SE, McIntosh MJ, Stablein D. Improved graft survival after renal transplantation in the United States, 1988 to 1996. N Engl J Med. 2000;342:605-12.

5. Vidhun J, Masciandro J, Varich L, Salvatierra O Jr, Sarwal M. Safety and risk stratification of percutaneous biopsies of adultsized renal allografts in infant and older pediatric recipients. Transplantation. 2003;76:552-7.

6. Zimmerli LU, Schiffer E, Zurbig P, et al. Urinary proteomic biomarkers in coronary artery disease. Mol Cell Proteomics. 2008;7:290-8.

7. Wu DL, Zhang WH, Wang WJ, Jing SB, Xu YM. Proteomic Evaluation of Urine from Renal Cell Carcinoma Using SELDITOF-MS and Tree Analysis Pattern. Technol Cancer Res Treat. 2008; 7:155-60.

8. Woodson K, O'Reilly KJ, Hanson JC, Nelson D, Walk EL, Tangrea JA. The usefulness of the detection of GSTP1 methylation in urine as a biomarker in the diagnosis of prostate cancer. J Urol. 2008;179:508-11. discussion 11-2.

9. Webb KS, Lin GH. Urinary fibronectin: potential as a biomarker in prostatic cancer. Invest Urol. 1980;17:401-4.

10. Thrailkill KM, Bunn RC, Moreau CS, et al. Matrix metalloproteinase-2 dysregulation in type 1 diabetes. Diabetes Care. 2007;30:2321-6.

11. Clarke W, Silverman BC, Zhang Z, Chan DW, Klein AS, Molmenti EP. Characterization of renal allograft rejection by urinary proteomic analysis. Ann Surg. 2003;237:660-664. discussion 4-5.

12. Vidal BC, Bonventre JV, I-HongHsu S. Towards the application of proteomics in renal disease diagnosis. Clin Sci(Lond). 2005;109:421-30.

13. Oetting WS, Rogers TB, Krick TP, Matas AJ, Ibrahim HN. Urinary beta2-microglobulin is associated with acute renal allograft rejection. Am J Kidney Dis. 2006;47:898-904.

14. Voshol H, Brendlen N, Muller D, et al. Evaluation of biomarker discovery approaches to detect protein biomarkers of acute renal allograft rejection. J Proteome Res. 2005;4:1192-9. 
15. Parikh CR, Jani A, Mishra J, et al. Urine NGAL and IL-18 are predictive biomarkers for delayed graft function following kidney transplantation. Am J Transplant. 2006;6:1639-45.

16. Zhou H, Pisitkun T, Aponte A, et al. Exosomal Fetuin-A identified by proteomics: a novel urinary biomarker for detecting acute kidney injury. Kidney Int. 2006;70:1847-57.

17. Wittke S, Haubitz M, Walden M, et al. Detection of acute tubulointerstitial rejection by proteomic analysis of urinary samples in renal transplant recipients. Am J Transplant. 2005;5:2479-88.

18. Decramer S, Gonzalezdeperedo A, Breuil B, et al. Urine in clinical proteomics. Mol Cell Proteomics. 2008;7(10):1850-62.

19. Jurgens M, Appel A, Heine G, et al. Towards characterization of the human urinary peptidome. Comb Chem High Throughput Screen. 2005;8:757-65.

20. Fiedler GM, Baumann S, Leichtle A, et al. Standardized peptidome profiling of human urine by magnetic bead separation and matrix-assisted laser desorption/ionization time-of-flight mass spectrometry. Clin Chem. 2007;53:421-8.

21. Schwartz GJ, Brion LP, Spitzer A. The use of plasma creatinine concentration for estimating glomerular filtration rate in infants, children, and adolescents. Pediatr Clin North Am. 1987;34:571-90.

22. Sigdel TK, Lau K, Schilling J, Sarwal M. Optimizing protein recovery for urinary proteomics, a tool to monitor renal transplantation. Clin Transplant. 2008;22:617-23.

23. Snyder SL, Sobocinski PZ. An improved 2, 4, 6trinitrobenzenesulfonic acid method for the determination of amines. Analytical Biochemistry. 1975;64:284-8.

24. Tibshirani R, Hastie T, Narasimhan B, et al. Sample classification from protein mass spectrometry, by 'peak probability contrasts'. Bioinformatics. 2004;20:3034-44.

25. Yasui Y, Pepe M, Thompson ML, et al. A data-analytic strategy for protein biomarker discovery: profiling of high-dimensional proteomic data for cancer detection. Biostatistics. 2003;4:449-63.

26. Habeeb AF. Determination of free amino groups in proteins by trinitrobenzenesulfonic acid. Anal Biochem. 1966;14:328-36.
27. Adachi J, Kumar C, Zhang Y, Olsen JV, Mann M. The human urinary proteome contains more than 1500 proteins, including a large proportion of membrane proteins. Genome Biol. 2006;7: R80.

28. Herrero M, Ibanez E, Cifuentes A. Capillary electrophoresiselectrospray-mass spectrometry in peptide analysis and peptidomics. Electrophoresis. 2008;29(10):2148-60.

29. Jacobs JM, Adkins JN, Qian WJ, et al. Utilizing human blood plasma for proteomic biomarker discovery. J Proteome Res. 2005;4:1073-85.

30. Kanie Y, Enomoto A, Goto S, Kanie O. Comparative RP-HPLC for rapid identification of glycopeptides and application in off-line LC-MALDI-MS analysis. Carbohydr Res. 2008;343:758-68.

31. Stodulkova E, Novak P, Deininger SO, et al. LC MALDI-TOF MS/MS and LC ESI FTMS analyses of HLA-B27 associated peptides isolated from peripheral blood cells. Immunol Lett. 2008;116:79-85.

32. Sadiq ST, Agranoff D. Pooling serum samples may lead to loss of potential biomarkers in SELDI-ToF MS proteomic profiling. Proteome Sci. 2008;6:16.

33. Khan A, Packer NH. Simple urinary sample preparation for proteomic analysis. J Proteome Res. 2006;5:2824-38.

34. Zhou H, Yuen PS, Pisitkun T, et al. Collection, storage, preservation, and normalization of human urinary exosomes for biomarker discovery. Kidney Int. 2006;69:1471-6.

35. Schaub S, Wilkins JA, Antonovici M, et al. Proteomic-based identification of cleaved urinary beta2-microglobulin as a potential marker for acute tubular injury in renal allografts. Am J Transplant. 2005;5:729-38.

36. Vio CP, Olavarria V, Gonzalez C, Nazal L, Cordova M, Balestrini C. Cellular and functional aspects of the renal kallikrein system in health and disease. Biol Res. 1998;31:305-22.

37. Villanueva J, Shaffer DR, Philip J, et al. Differential exoprotease activities confer tumor-specific serum peptidome patterns. J Clin Invest. 2006;116:271-84. 